\title{
Studi Deskriptif Tingkat Pengetahuan Akseptor KB Tentang Alat Kontrasepsi Pil Kombinasi
}

Yuhemy Zurizah

Akbid Budi Mulia Palembang

Informasi Artikel :

Diterima : 08 April 2021

Direvisi : 15 April 2021

Disetujui : 29 Mei 2021

Diterbitkan : 15 Juni 2021

"Korespondensi Penulis : Yuhemyz@gmail.com

\section{A B S T R A K}

Laju pertumbuhan penduduk (LPP) Indonesia memiliki kecenderungan menurun. Kebijakan pemerintah untuk menekan LPP dengan adanya program Keluarga Berencana (KB) yang diluncurkan pada tahun 1980an semakin nyata hasilnya. Pada tahun 1971-1980 pertumbuhan penduduk Indonesia masih cukup tinggi sekitar 2,33 persen. Pertumbuhan penduduk ini kemudian mengalami penurunan yang cukup tajam hingga mencapai 1,44 persen pada 1990-2000. Penurunan ini antara lain disebabkan berkurangnya tingkat kelahiran sebagai dampak peran serta masyarakat dalam program KB. Namun pada periode sepuluh tahun berikutnya, tepatnya awal masa reformasi tahun 2000-2010 laju pertumbuhan ini mengalami sedikit peningkatan sekitar 0,05 persen. Laju pertumbuhan penduduk apabila tidak dikendalikan berakibat pada meningkatnya jumlah penduduk.Penelitian ini ingin mengungkapkan bagaimana gambaran tingkat pengetahuan Akseptor KB tentang Pil Kombinasi di Desa Mainan kecamatan Sembawa Kabupaten Banyuasin. Penelitian ini bertujuan untuk mengetahui gambaran tingkat pengetahuan akseptor KB tentang Alat kontrasepsi Pil kombinasi Desain penelitian ini menggunakan studi deskriptif. Tehnik pengambilan sampling dengan non probability sampling yaitu porposive sampling sedangkan tehnik analisanya adalah univariate yang dilakukan terhadap tiap variable dari hasil penelitian. Sample yang digunakan adalah 44 responden. Data yang dikumpulkan berasal dari data primer dan data sekunder dengan menggunakan kuesioner. Dari hasil penelitian didapatkan hasil mayoritas responden memiliki tingkat pengetahuan yang kurang sebanyak $22(50 \%)$ responden,tingkat pengetahuan cukup sebanyak 12 ( $27,27 \%)$ responden dan tingkat pengetahuan baik sebanyak $10(22,72 \%)$. Akhir dari kesimpulannya adalah tingkat pengetahuan responden yang kurang, kemudian dapat disarankan kepada petugas kesehatan untuk lebih meningkatkan kualitas pelayanan KB dengan konseling Pil Kombinasi.

Kata Kunci : Tingkat pengetahuan, Alat kontrasepsi Pil kombinasi

\section{ABSTRACT}

Indonesia's population growth rate (LPP) has a downward trend. The government's policy to put pressure on the LPP with the Family Planning (KB) program launched in the 1980s had increasingly tangible results. In 1971-1980, Indonesia's population growth was quite high, around 2.33 percent. This population growth then experienced a sharp decline to reach 1.44 percent in 1990-2000. This decrease was partly due to a decrease in the birth rate as a result of the community being involved in the family planning program. However, in the following ten years, to be precise at the beginning of the reform period in 2000-2010, the growth rate began to increase by around 0.05 percent. Uncontrolled population growth rate has an impact on population. This research wish to lay open how picture mount knowledge of 
acceptor of KB about Pill Combination in Countryside of Mainan Sari District of Sembawa of Sub-Province of Banyuasin. This Research aim to to know picture mount knowledge of acceptor of KB about Intrauterine device Pill combination of Desain this research use descriptive study. Technics of intake of sampling with non sampling probality that is perposive of sampling while is technics of its analysis is conducted univariate to every variable from result of research. Sample the used is 44 responder. Collected data come from primary data and data of sekunder by using kuesioner. From result of research got by result of responder majority have less knowledge storey;level counted 22 ( 50 ) knowledge responden,tingkat enough counted 12 ( 27,27) storey;level and responder knowledge of goodness counted 10 ( 22,72). End of its conclusion level knowledge of less responder, later then can be suggested to officer of health to be more improve the quality of service of KB with Pill Combination konseling.

Keywords: Mount knowledge, Intrauterine device Pill Combination

\section{PENDAHULUAN}

Menurut World Population Data Sheet 2013, Indonesia merupakan Negara ke-5 di dunia dengan estimasi jumlah penduduk terbanyak, yaitu 249 juta. Diantara Negara ASEAN, Indonesia dengan luas wilayah terbesar tetap menjadi Negara dengan penduduk terbanyak, jauh di atas 9 negara anggota lain. Dengan Angka fertilitas atau Total Fertility Rate (TFR), Indonesia masih berada dia atas rata-rata TFR negara ASEAN, yaitu 2,4.(InfoDATIN, 2014).

Laju pertumbuhan penduduk (LPP) Indonesia memiliki kecenderungan menurun. Kebijakan pemerintah untuk menekan LPP dengan adanya program Keluarga Berencana (KB) yang diluncurkan pada tahun 1980an semakin nyata hasilnya. Pada tahun 19711980 pertumbuhan penduduk Indonesia masih cukup tinggi sekitar 2,33 persen. Pertumbuhan penduduk ini kemudian mengalami penurunan yang cukup tajam hingga mencapai 1,44 persen pada 19902000. Penurunan ini antara lain disebabkan berkurangnya tingkat kelahiran sebagai dampak peran serta masyarakat dalam program KB. Namun pada periode sepuluh tahun berikutnya, tepatnya awal masa reformasi tahun 2000-2010 laju pertumbuhan ini mengalami sedikit peningkatan sekitar 0,05 persen. Laju pertumbuhan penduduk apabila tidak dikendalikan berakibat pada meningkatnya jumlah penduduk. Dalam kurun waktu lima tahun terakhir (2010-2015)

laju pertumbuhan penduduk Indonesia kembali mengalami penurunan menjadi 1,43 persen.(BPS, 2020)

Total jumlah penduduk Sumatera Selatan dari hasil sensus yang berjalan dari Februari hingga September 2020 adalah $8,467,432$ jiwa, dengan laju pertumbuhan penduduk 1,25 persen. Jumlah ini naik dibandingkan sensus tahun 2010 yang sebanyak 7,450,394 jiwa. Jumlah penduduk Sumsel kurang lebih hampir 8,5 juta jiwa dengan kepadatan penduduk 92 jiwa per kilometer(Endang, 2021).

Untuk mengatur laju pertumbuhan penduduknya, salah satu cara yang dilakukan oleh pemerintah, yaitu dengan melaksanakan Program keluarga Berencana yang mampu menerapkan Keluarga Kecil Bahagia dan Sejahtera (NKKBS), yang berorientasi pada catur warga atau zero population growth (pertumbuhan seimbang) (Manuaba,2018).

Keluarga Berencana sendiri terdiri beberapa alat kontrasepsi seperti suntik, PIL, susuk, kondom, IUD, sterilisasi wanita (MOW), dan sterilisasi pria (MOP). Pemakaian alat kontrasepsi ini diharapkan dapat membantu pasangan suami istri untuk mewujudkan keluarga berkualitas yang menjadi visi dari Program KB ini (Sarwono, 2010).

Pil KB merupakan salah satu metode KB hormonal yang mengandung 2 hormon, yaitu hormon estrogen dan hormon progesteron. Dengan metode hormonal ini, 
kedua hormon tersebut menghalangi indung telur ( ovarium ) sehingga tidak melepas sel telur kedalam rahim, selain itu metode ini juga menyebabkan lendir dimulut rahim menjadi sangat kental, sehingga menghalangi sperma bila hendak masuk (Dhanardono, 2018). Namun kedua hormon tersebut juga mempunyai efek samping. Efek sampingnya dikarenakan kelebihan hormon estrogen dan hormon progesteron. Efek dari kelebihan hormon estrogen yang sering terjadi antara lain rasa mual, retensi cairan, sakit kepala, nyeri payudara dan keputihan. Sedangkan efek samping karena kelebihan hormon progesterone dapat menyebabkan haid tidak teratur, bertambahnya nafsu makan disertai bertambahnya berat badan dan jerawat (Dhanardono, 2008 ).

Dari data Statistik Demografi dan Kesehatan Indonesia ( SDKI ) tahun 2012 menunjukkan tren Prevalensi Penggunaan Kontrasepsi atau Contraceptive Prevalence Rate (CPR) di Indonesia sejak 1991-2012 cenderung meningkat, sementara tren Angka Fertilitas atau Total Fertility Rate (TFR) cenderung menurun. Tren ini mengggambarkan bahwa meningkatnya cakupan wanita usia 15-49 tahun melakukan

$\mathrm{KB}$ sejalan dengan menurunnya angka fertilitas nasional. Bila dibandingkan dengan target RPJMN 2014, CPR telah melampaui target $(60,1 \%)$ dengan capaian $61,9 \%$ namun TFR belum mencapai target $(2,36)$ dengan angka tahun 2012 sebesar 2,6 (InfoDATIN, 2014)

Menurut data dari umpan balik program KB nasional di Sumatera Selatan sampai dengan Desember 2017, pada pemakaian alat kontrasepsi Suntik hasil yang dicapai $67,56 \%$, dengan target $129,77 \%$, PiL hasil yang dicapai $17,82 \%$ dengan target $76.99 \%$, Implant hasil yang dicapai $6,77 \%$ dengan target $117.07 \%$, IUD hasil yang dicapai $2,74 \%$ dengan target $4,59 \%$, Kondom hasil yang dicapai $2,23 \%$ dengan target $78,10 \%$, MOW hasil yang dicapai 2, 23\% dengan target $78,10 \%$, MOP hasil yang dicapai $0,37 \%$ dengan target $22,43 \%$. (Umpan Balik KB, 2018).
Kota Palembang masih mendominasi jumlah penduduk di Provinsi Sumatera Selatan berdasarkan hasil sensus penduduk tahun 2020 oleh Badan Pusat Statistik Sumsel. Palembang memiliki jumlah penduduk 1,6 juta jiwa atau 19,71 persen dari total penduduk Sumsel. Penduduk Sumsel masih terkonsentrasi di Kota Palembang dengan jumlah 1,6 juta jiwa, sementara paling sedikit di Pagar Alam dengan jumlah 143 ribu jiwa (Endang, 2021).

Di kecamatan Sembawa sendiri terdiri dari 10 desa, salah satu desa yang penggunaan alat kontrasepsi Pilnya belum memenuhi target yang diinginkan yaitu $76,00 \%$ adalah desa Mainan dimana jumlah pemakaian $\mathrm{KB}$ pilnya adalah sebesar 50 $(14,16 \%)$ dengan jumlah PUS 444 orang. (Laporan PLKB Sembawa, 2020).

Dari beberapa penelitian menunjukkan bahwa tingkat pengetahuan klien akan berpengaruh terhadap pemilihan metode kontrasepsi yang akan digunakan. Adapun faktor - faktor yang mempengaruhi pengetahuan seseorang yaitu pendidikan, paparan, media massa, sosial ekonomi, hubungan sosial, pengalaman, sikap, kepercayaan, dan norma sosial (Notoatmodjo,2003).

Berdasarkan data yang penulis peroleh di Desa Mainan, Kecamatan Sembawa, Kabupaten Banyuasin, penulis tertarik untuk melakukan penelitian dengan judul Studi Deskruptif Tingkat Pengetahuan Akspetor KB Tentang Alat Kontrasepsi Pil Kombinasi.

\section{METODE PENELITIAN}

Desain penelitian ini menggunakan studi deskriptif. Penelitian deskriptif adalah penelitian diarahkan untuk mendeskripsikan atau menguraikan suatu keadaan didalam suatu komunitas (Notoatmodjo, 2014). Penelitian ini hanya mendeskripsikan atau menggambarkan Tingkat Pengetahuan Akseptor KB Tentang Pil Kombinasi di Desa Mainan Kecamatan Sembawa Kabupaten Banyuasin.

Populasi dalam penelitian ini adalah Akseptor KB Pil Kombinasi yang bertempat 
tinggal di Desa Mainan Kecamatan Sembawa Kabupaten Banyuasin sebanyak 210 orang. Sampel dalam penelitian ini berdasarkan perhitungan jumlah sampel menjadi 44 orang. Penelitian ini dilakukan pada bulan Februari - Maret 2021 di Desa Mainan Kecamatan Sembawa Kabupaten Banyuasin.

Dalam penelitian ini instrument yang diguanakan adalah kuesioner yang berisikan karaketeristik responden yang meliputi umur, pekerjaan, paritas, alat kontrasepsi yang sedang digunakan. Kuesioner yang digunakan dalam penelitian ini adalah kuesioner tertutup, yaitu sudah disediakan jawabannya sehingga responden tinggal memilih (Swarjana,2015). Analisa data dalam penelitian ini menggunakan angka univariate yang dilakukan terhadap tidap variabel dari hasil penelitian.

\section{HASIL PENELITIAN}

\section{Tingkat Pengetahuan}

Responden dalam penelitian ini adalah Akseptor KB tentang Pil Kombinasi di Desa Mainan Kecamatan Sembawa Kabupaten Banyuasin pada bulan Februari 2021, dengan jumlah responden sebanyak 44 orang. Data yang diperoleh berasal dari jawaban tiap-tiap soal pada lembar kuesioner yang meliputi :

Keluarga Berencana, Kontrasepsi, Pengertian Pil Kombinasi, Kemasan Pil Kombinasi, Keefektifan Pil Kombinasi, Indikasi Pil Kombinasi, Kontra Indikasi Pil Kombinasi, Keuntungan Pil Kombinasi, Kerugian Pil Kombinasi, Efek samping Pil Kombinasi dan intruksi pada klien.

Berikut tabel dan hasil analisa yang berasal dari jawaban tiap-tiap soal pada lembar kuesioner yang diberikan pada akseptor KB di Desa Mainan Kecamatan Sembawa Kabupaten Banyuasin.

a. Keluarga Berencana

Tabel 1. Tingkat Pengetahuan Akseptor KB tentang alat kontrasepsi Pil Kombinasi mengenai Keluarga Berencana

\begin{tabular}{ccc}
$\begin{array}{c}\text { Keluarga } \\
\text { Berencana }\end{array}$ & f & $\begin{array}{c}\text { Prosentase } \\
(\boldsymbol{\%})\end{array}$ \\
\hline Baik & 26 & 59.09 \\
\hline Cukup & 9 & 20.45 \\
\hline Kurang & 9 & 20.45 \\
\hline Jumlah & 44 & 100 \\
\hline
\end{tabular}

Berdasarkan tabel 1 dapat dijelaskan bahwa mayoritas Responden tentang Keluarga Berencana baik 59,09\% (26 orang), dibandingkan dengan yang memiliki tingkat pengetahuan cukup dan kurang 20,45\% (9 orang).

b. Kontrasepsi

Tabel 2 Tingkat Pengetahuan Akseptor KB tentang alat kontrasepsi Pil Kombinasi Kontrasepsi

\begin{tabular}{ccc}
\hline Kontrasepsi & f & Prosentase (\%) \\
\hline Baik & 26 & 59.09 \\
Cukup & 0 & 0 \\
Kurang & 18 & 40.91 \\
\hline Jumlah & 44 & 100 \\
\hline
\end{tabular}

Pada tabel 2 dapat dijelaskan bahwa Mayoritas Responden tentang kontrasepsi baik 59,0 9\% (26 orang), dibandingkan dengan yang memiliki tingkat pengetahuan kurang 40, 91\% (18 orang ).

c. Pengertian Pil Kombinasi

Tabel 3 Tingkat Pengetahuan Akseptor KB tentang alat kontrasepsi Pil Kombinasi mengenai Pengertian Pil Kombinasi

\begin{tabular}{ccc}
\hline Kontrasepsi & f & Prosentase (\%) \\
\hline Baik & 25 & 56.82 \\
Cukup & 0 & 0 \\
Kurang & 19 & 43.18 \\
\hline Jumlah & 44 & 100 \\
\hline
\end{tabular}

Berdasakan tabel 3 dapat dijelaskan bahwa Mayoritas Responden tentang Pengertian Pil Kombinasi baik 56,82\% (25 orang ), dibandingkan dengan yang 
memiliki tingkat pengetahuan kurang $43,18 \%$ (19 orang).

d. Kemasan Pil Kombinasi

Tabel 4 Tingkat Pengetahuan Akseptor KB mengenai Kemasan Pil Kombinasi

Kemasan Pil f $\quad$ Prosentase (\%) Kombinasi

Baik $\quad 30 \quad 68.18$

Cukup $\quad 0$

0

\begin{tabular}{ccc} 
Kurang & 14 & 31.82 \\
\hline Jumlah & 44 & 100
\end{tabular}

Berdasarkan tabel 4 dapat dijelaskan bahwa Mayoritas Responden tentang Kemasan Pil Kombinasi baik 68,18\% (30 orang), dibandingkan dengan yang memiliki tingkat pengetahuan kurang 31 , $82 \% 14$ orang).

e. Keefektifan Pil Kombinasi

Tabel 5 Tingkat Pengetahuan Akseptor KB mengenai Keefektifan Pil Kombinasi

\begin{tabular}{ccc}
\hline $\begin{array}{c}\text { Keefektifan Pil } \\
\text { Kombinasi }\end{array}$ & f & $\begin{array}{c}\text { Prosentase } \\
(\boldsymbol{\%})\end{array}$ \\
\hline Baik & 27 & 61.36 \\
Cukup & 0 & 0 \\
Kurang & 17 & 38.64 \\
\hline Jumlah & 44 & 100 \\
\hline
\end{tabular}

Berdasarkam tabel 5 dapat dijabarkan bahwa ayoritas Responden tentang Keefektifan Pil Kombinasi baik $61,36 \%$ (27 orang), dibandingkan dengan yang memiliki tingkat pengetahuan kurang $38,64 \%$ (17 orang).

f. Indikasi Pil Kombinasi

Tabel 6 Tingkat Pengetahuan Akseptor KB tentang Pil Kombinasi mengenai indikasi Pil Kombinasi

\begin{tabular}{ccc}
\hline $\begin{array}{c}\text { Indikasi Pil } \\
\text { Kombinasi }\end{array}$ & f & $\begin{array}{c}\text { Prosentase } \\
(\boldsymbol{\%})\end{array}$ \\
\hline Baik & 25 & 56.82 \\
Cukup & 0 & 0 \\
Kurang & 19 & 43.18 \\
\hline Jumlah & 44 & 100 \\
\hline
\end{tabular}

Berdasarkan tabel 6 dapat dijelaskan bahwa mayoritas Responden tentang Indikasi Pil Kombinasi baik 56,82\% (25 orang), dibandingkan dengan yang memiliki tingkat pengetahuan kurang 43, 18\% (19 orang).

g. Kontraindikasi Pil Kombinasi

Tabel 7 Tingkat Pengetahuan Akseptor $\mathrm{KB}$ tentang Pil kombinasi mengenai kontraindikasi Pil Kombinasi

\begin{tabular}{ccc}
\hline $\begin{array}{c}\text { Kontraindikasi Pil } \\
\text { Kombinasi }\end{array}$ & f & $\begin{array}{c}\text { Prosentase } \\
(\mathbf{\%})\end{array}$ \\
\hline Baik & 28 & 63.64 \\
Cukup & 0 & 0 \\
Kurang & 16 & 36.36 \\
\hline Jumlah & 44 & 100 \\
\hline
\end{tabular}

Berdasarkan Tabel 7 dapat diketahui bahwa ayoritas Responden tentang Kontraindikasi Pil Kombinasi baik $63,64 \%$ (28 orang), dibandingkan dengan yang memiliki tingkat pengetahuan kurang $36,36 \%$ (16 orang ).

h. Keuntungan Pil Kombinasi

Tabel 8 Tingkat pengetahuan Akseptor KB tentang Pil Kombinasi mengenai keuntungan Pil Kombinasi

\begin{tabular}{ccc}
\hline $\begin{array}{c}\text { Keuntungan Pil } \\
\text { Kombinasi }\end{array}$ & f & $\begin{array}{c}\text { Prosentase } \\
(\%)\end{array}$ \\
\hline Baik & 14 & 31.82 \\
Cukup & 12 & 27.27 \\
Kurang & 18 & 40.91 \\
\hline Jumlah & 44 & 100
\end{tabular}


Berdasarkan Tabel 8 dapat dijelaskan bahwa mayoritas Responden tentang Keuntungan Pil Kombinasi kurang $40,91 \%$ (18 orang), dibandingkan dengan yang memiliki tingkat pengetahuan baik $31,82 \%$ (14 orang) dan cukup 27,27\% (12 orang).

i. Kerugian Pil Kombinasi

Tabel 9 Tingkat Pengetahuan Akseptor KB tentang Pil Kombinasi mengenai kerugian Pil Kombinasi

\begin{tabular}{ccc}
\hline $\begin{array}{c}\text { Kerugian Pil } \\
\text { Kombinasi }\end{array}$ & f & Prosentase (\%) \\
\hline Baik & 14 & 31.82 \\
Cukup & 0 & 0 \\
Kurang & 30 & 68.18 \\
\hline Jumlah & 44 & 100 \\
\hline
\end{tabular}

Berdasarkan Tabel 9 dapat dijelaskan bahwa mayoritas Responden tentang Kerugian Pil Kombinasi kurang $68,18 \%$ (30 orang), dibandingkan dengan yang memiliki tingkat pengetahuan baik $31,82 \%$ (14 orang).

j. Efek Samping

Tabel 10 Tingkat Pengetahuan Akseptor KB tentang Pil Kombinasi mengenai

\begin{tabular}{ccc}
\hline $\begin{array}{c}\text { Efek Samping Pil } \\
\text { Kombinasi }\end{array}$ & f & $\begin{array}{c}\text { Prosentase } \\
(\mathbf{\%})\end{array}$ \\
\hline Baik & 18 & 40.91 \\
Cukup & 0 & 0 \\
Kurang & 26 & 59.09 \\
\hline Jumlah & 44 & 100
\end{tabular}

Berdasarkan Tabel 10 dapat dijelaskan bahwa mayoritas Responden tentang Efek Samping Pil Kombinasi kurang 59,09\% (26 orang), dibandingkan dengan yang memiliki tingkat pengetahuan baik 40, 91\% (18 orang). k. Intruksi Kepada Klien

Tabel 11Tingkat Pengetahuan Akseptor KB tentang Pil Kombinasi mengenai intruksi kepada klien

\begin{tabular}{ccc}
\hline $\begin{array}{c}\text { Intruksi Kepada } \\
\text { Klien }\end{array}$ & f & Prosentase (\%) \\
\hline Baik & 12 & 27.27 \\
Cukup & 3 & 6.82 \\
Kurang & 29 & 65.91 \\
\hline Jumlah & 44 & 100 \\
\hline
\end{tabular}

Berdasarkan Tabel 11 dapat diketahui bahwa mayoritas responden tentang Intruksi Kepada Klien kurang $65,91 \%$ (29 orang), dibandingkan dengan yang memiliki tingkat pengetahuan baik $27,27 \%$ (12 orang) dan tingkat pengetahuan cukup $6,82 \%$ (3 orang).

3 Tingkat Pengetahuan Akseptor KB tentang Pil Kombinasi

Responden dalam penelitian ini adalah Akseptor KB tentang Pil Kombinasi di Desa Mainan Kecamatan Sembawa Kabupaten Banyuasin pada bulan Februari 2021. Adapun jumlah responden sebanyak 44 orang. Data yang diperoleh berupa tingkat pengetahuan Akseptor KB tentang Pil Kombinasi di Desa Mainan Kecamatan Sembawa Kabupaten Banyuasin pada Bulan Februasi 2021 Setelah dilakukan penelitian dengan menggunakan kuesioner didapatkan hasil yang dapat dilihat pada tabel di bawah ini :

Tabel 12 Tingkat Pengetahuan Akseptor KB tentang Pil Kombinasi

\begin{tabular}{ccc}
\hline $\begin{array}{c}\text { Tingkat } \\
\text { Pengetahuan }\end{array}$ & f & $\begin{array}{c}\text { Prosentase } \\
(\%)\end{array}$ \\
\hline Baik & 10 & 22.73 \\
Cukup & 12 & 27.27 \\
Kurang & 22 & 50 \\
\hline Jumlah & 44 & 100 \\
\hline
\end{tabular}


Berdasarkan tabel 12 dapat diketahui bahwa Tingkat Pengetahuan Akseptor KB tentang Pil Kombinasi di Desa Gondang Sari Kecamatan Banyubiru Kabupaten Semarang adalah kurang 22 orang ( $50 \%$ ), dibandingkan dengan yang mempunyai tingkat pengetahuan cukup $27,27 \%$ dan tingkat pengetahuan baik $22,73 \%$.

\section{B PEMBAHASAN}

Pada sub bab ini akan dibahas hasil penelitian tingkat pengetahuan Akseptor KB tentang Pil Kombinasi di Desa Mainan Kecamatan Sembawa Kabupaten Banyuasin Tahun 2021.

\section{Tingkat Pengetahuan Akseptor KB} tentang Pil Kombinasi

a. Tingkat Pengetahuan Akseptor KB mengenai Keluarga Berencana

Tingkat Pengetahuan Akseptor KB mengenai Keluarga Berencana, sebagian besar mempunyai tingkat pengetahuan baik sebanyak 26 orang $(59,09 \%)$. Hal ini kemungkinan karena Akseptor KB telah mendapat informasi dari berbagai sumber media yang memuat tentang Keluarga Berencana.

b. Tingkat Pengetahuan Akseptor KB mengenai kontrasepsi

Tingkat Pengetahuan Akseptor KB mengenai kontrasepsi, sebagian besar mempunyai tingkat pengetahuan baik sebanyak 26 orang $(59,09 \%)$. Hal ini kemungkinan karena Akseptor KB telah mendapat informasi dari berbagai sumber media yang memuat tentang Kontrasepsi.

c. Tingkat Pengetahuan Akseptor KB mengenai pengertian Pil Kombinasi

Tingkat Pengetahuan Akseptor KB mengenai pengertian Pil Kombinasi, sebagian besar mempunyai tingkat pengetahuan baik sebanyak 25 orang $(56,82 \%)$. Hal ini kemungkinan karena Akseptor $\mathrm{KB}$ telah mendapat informasi dari berbagai sumber media yang memuat tentang pengertian Pil Kombinasi.

d. Tingkat Pengetahuan Akseptor KB mengenai kemasan Pil Kombinasi

Tingkat Pengetahuan Akseptor KB mengenai kemasan Pil Kombinasi, sebagian besar mempunyai tingkat pengetahuan baik sebanyak 30 orang $(68,18 \%)$. Hal ini kemungkinan karena Akseptor KB telah mendapat informasi dari berbagai sumber media yang memuat tentang kemasan Pil Kombinasi.

e. Tingkat Pengetahuan Akseptor KB mengenai keefektifan Pil Kombinasi

Tingkat Pengetahuan Akseptor KB mengenai keefektifan Pil Kombinasi, sebagian besar mempunyai tingkat pengetahuan baik sebanyak 27 orang (61,36\%). Hal ini kemungkinan karena Akseptor KB telah mendapat informasi dari berbagai sumber media yang memuat tentang keefektifan Pil Kombinasi.

f. Tingkat Pengetahuan Akseptor KB mengenai indikasi Pil Kombinasi

Tingkat Pengetahuan Akseptor KB mengenai indikasi Pil Kombinasi, sebagian besar mempunyai tingkat pengetahuan baik sebanyak 25 orang $(56,82 \%)$. Hal ini kemungkinan karena Akseptor KB telah mendapat informasi mengenai indikasi Pil Kombinasi seperti, telah memiliki anak, anemia karena haid berlebih, setelah melahirkan dan tidak menyusui, setelah keguguran.

g. Tingkat Pengetahuan Akseptor KB mengenai kontraindikasi Pil Kombinasi

Tingkat pengetahuan Akseptor KB mengenai kontraindikasi, sebagian besar mempunyai tingkat pengetahuan baik sebanyak 28 orang $(63,64 \%)$. Hal ini kemungkinan karena Akseptor $\mathrm{KB}$ telah mendapat informasi mengenai kontraindikasi Pil Kombinasi seperti hamil, menyusui, penyakit hati (hepatitis) 
dan perdarahan pervagina yang belum diketahui penyebabnya.

h. Tingkat Pengetahuan Akseptor KB mengenai keuntungan Pil Kombinasi

Tingkat Pengetahuan Akseptor KB mengenai keuntungan Pil Kombinasi, sebagian besar mempunyai tingkat pengetahuan kurang sebanyak 18 orang $(40,91 \%)$. Hal ini dikarenakan kurang mengetahuinya Akseptor KB tentang keuntungan Pil Kombinasi, seperti melindungi wanita dari penyakit radang panggul, mengurangi kejadian kehamilan ektopik, tidak mengganggu senggama.

i. Tingkat Pengetahuan Akseptor KB mengenai kerugian Pil Kombinasi

Tingkat Pengetahuan Akseptor KB mengenai kerugian Pil Kombinasi, sebagian besar mempunyai tingkat pengetahuan kurang sebanyak 30 orang $(68,18 \%)$. Hal ini dikarenakan kurang mengetahuinya Akseptor KB tentang kerugian Pil Kombinasi, seperti tidak boleh digunakan pada wanita menyusui, perdarahan bercak, mual dan tidak mencegah dari penyakit kelamin.

j. Tingkat Pengetahuan Akseptor KB mengenai efek samping Pil kombinasi

Tingkat Pengetahuan Akseptor KB mengenai efek samping Pil Kombinasi, sebagian besar mempunyai tingkat pengetahuan kurang sebanyak 26 orang $(59,09 \%)$. Hal ini dikarenakan kurang mengetahuinya Akseptor KB tentang efek samping Pil Kombinasi seperti perdaahan bercak, mual, perubahan emosi dan nyeri payudara.

k. Tingkat Pengetahuan Akseptor KB mengenai intruksi kepada klien

Tingkat Pengetahuan Akseptor KB mengenai intruksi kepada klien, sebagian besar mempunyai tingkat pengetahuan kurang sebanyak 29 orang $(65,91 \%)$. Hal ini dikarenakan kurang mengetahuinya Akseptor KB tentang intruksi kepada klien seperti sebaiknya diminum setiap hari, pil pertama dimulai pada hari pertama siklus haid dan bila muntah dalam 2 jam segera minum pil yang baru.

\section{Tingkat Pengetahuan Akseptor KB tentang Pil Kombinasi}

Dari hasil keseluruhan penelitian diatas diperoleh Tingkat Pengetahuan Akseptor KB tentang Pil Kombinasi di Desa Mainan Kecamatan Sembawa Kabupaten Banyuasin mayoritas berpengetahuan kurang sebanyak 22 orang (50\%), cukup sebanyak 12 orang $(27,72 \%)$ dan baik 10 orang $(27,27 \%)$.

\section{KESIMPULAN}

Tingkat pengetahuan Akseptor KB tentang Pil Kombinasi di Desa Sukajadi Kecamatan Talang Kelapa Kabupaten Banyuasin pada bulan Februari 2021 mayoritas memiliki tingkat pengetahuannya kurang. Yaitu sebanyak 22 responden (50\%), sedangkan tingkat pengetahuan yang cukup sebanyak 12 responden $(27,27 \%)$ dan hanya 10 responden $(22.72 \%)$ mempunyai tingkat pengetahuan baik.

\section{DAFTAR PUSTAKA}

Balitbangkes.2013.Kebijakan pemerintah tentang $K b$.

BKKBN.2012.Jumlah PUS dengan Keluarga Berencana.

Dinas Kesehatan Sumatera Selatan. 2013. Profil Kesehatan Provinsi Sumatera Selatan Tahun 2010. Dinkes Provinsi Sumatera Selatan, Palembang.

Dinas Kesehatan Kota Palembang. 2014. Profil Kesehatan Kota Palembang Tahun 2013. Palembang.

Endang, Tri Wahyuningsih.2021.Penduduk Palembang Terpadat di Sumsel. https://infopublik.id/kategori/nusantara 1504647/penduduk-palembang- 
Jurnal Kebidanan : Jurnal Medical Science Ilmu Kesehatan Akademi Kebidanan Budi Mulia Palembang Volume.11 No.1, Juni 2021

Available online http://journal.budimulia.ac.id/

terpadat-di-sumsel.Diakses tanggal 22 Januari 2021.

InfoDATIN.2014.Situasi dan Analisis Keluarga Berencana.

https:pusdatin.kemkes.go.id. Diakses tanggal 27 Februari 2021.

Kemenkes RI. 2013. Riset Kesehatan Dasar.

Jakarta: Badan Penelitian Dan

Pengembangan Kesehatan Departemen

Kesehatan Republik Indonesia.

Swarjana, I Ketut.2015.Metodologi Penelitian Kesehatan (Edisi

Revisi).Penerbit ANDI. Yogyakarta. 
